\title{
Diagnostic Imaging of Schizencephaly: About 16 Cases
}

\author{
M. Badraoui*, D. Basraoui, H. Jalal
}

Department of Pediatric Radiology, Mother and Child Hospital, Marrakech, Morocco

DOI: $10.36347 /$ sjmcr.2020.v08i02.038

| Received: 27.01.2020 | Accepted: 03.02.2020 | Published: 27.02.2020

*Corresponding author: Marouane Badraoui

\section{Abstract}

\section{Original Research Article}

Schizencephaly is a malformation of the central nervous system related to the presence of an extended unilateral or bilateral cleft of the lateral ventricle on the surface of the cerebral cortex. This is a retrospective and descriptive study of 16 cases of schizencephaly collected over a period of 8 years (January 2011 to December 2019). A radiological assessment made of a brain scan performed in 11 patients and a cerebral MRI performed in 5 patients. The reported cases ranged in age from 2 months to 45 years with a male predominance and a sex ratio of 1.66 . The clinical symptomatology was dominated by epileptic seizures, psychomotor retardation and motor deficit. The malformations were divided as follows: unilateral schizencephaly (15 cases: 6 type I and 9 type II) and bilateral schizencephaly (1 case: type II). Schizencephaly is an uncommon cerebral malformation that is most often revealed by epilepsy. It is characterized by a cleft with open or closed lips sitting most often in the Rolandic regions. Imaging, especially MRI, is essential in the positive diagnosis and the assessment of lesions.

Keywords: Schizencephaly, malformation, imaging.

Copyright @ 2020: This is an open-access article distributed under the terms of the Creative Commons Attribution license which permits unrestricted use, distribution, and reproduction in any medium for non-commercial use (NonCommercial, or CC-BY-NC) provided the original author and source are credited.

\section{INTRODUCTION}

Schizencephaly is a malformation of the central nervous system related to the presence of an extended unilateral or bilateral cleft of the lateral ventricle on the surface of the cerebral cortex. Sectional imaging plays an important role in positive diagnosis and in the assessment of injury [1].

\section{Goals}

- To show the role of imaging in the diagnosis of schizencephaly.

- Illustrate the types of schizencephalia and abnormalities that may be associated.

\section{Materials ANd Methods}

This is a retrospective and descriptive study of 16 cases of schizencephaly collected over a period of 8 years (January 2011 to December 2019). A radiological assessment made of a brain scan performed in 11 patients and a cerebral MRI performed in 5 patients.

\section{RESULTS}

The reported cases ranged in age from 2 months to 45 years with a male predominance and a sex ratio of 1.66. The clinical symptomatology was dominated by epileptic seizures ( 8 cases), psychomotor retardation ( 5 cases) and motor deficit ( 3 cases). The malformations were divided as follows: unilateral schizencephaly in 15 cases: 6 closed-slit type I cases (Figure-1) and 9 open-slit type II cases (Figure $2 \& 3$ ) and bilateral schizencephaly in 1 case: type II.

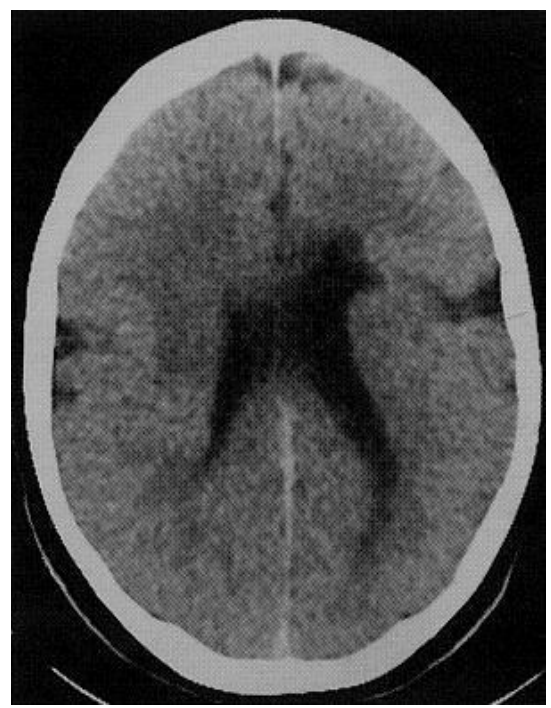

Fig-1: CT scan in axial sections without PDC injection: Schizophrenia type I, note the small protrusion of the frontal horn opposite 


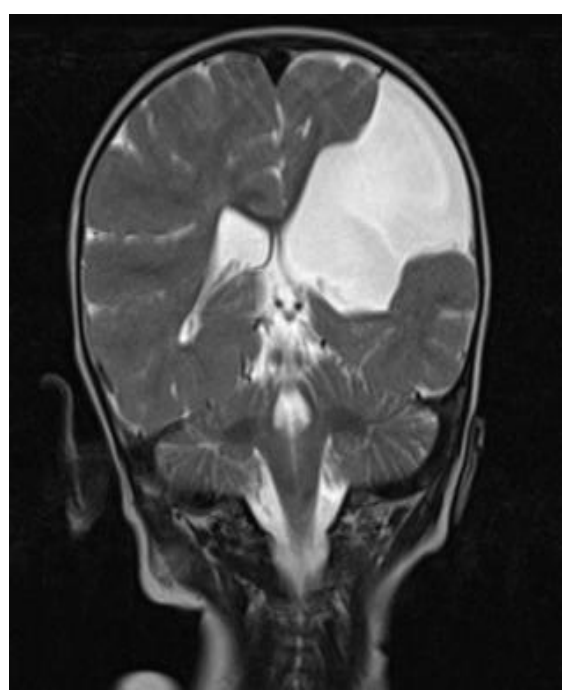

Fig-2: Cerebral MRI in T2 coronal: left parietal schizencephaly with open slit

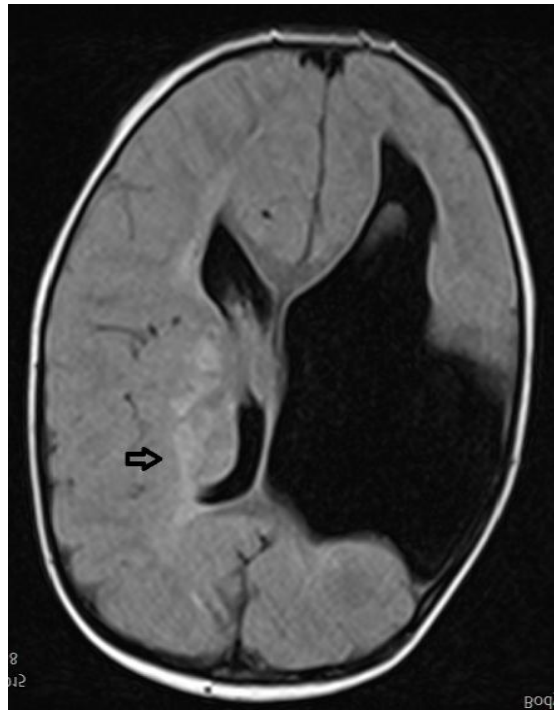

Fig-3: Cerebral MRI in T2 flair: left parietal schizencephaly with open slit

\section{DISCUSSION}

Schizencephaly is a rare disorder of cerebral cortical development. It results from a defect in cerebral perfusion at a critical period of neuronal migration towards the $7^{\text {th }}$ week of gestation [2].

The most discussed etiologies are chemia in utero, CMV or toxoplasma gondii infection and a genetic cause: deficiency in the EMX2 gene [3].

Imaging (CT and MRI) plays a key role in the positive diagnosis and the assessment of lesions. We distinguish schizencephaly type I or closed slit (20\% of cases) and schizencephaly type II or open or cystic slit ( $80 \%$ of cases) [4].

Cystic schizencephaly results in the presence of a uni-or bilateral fluid cavity extending from the cortical surface to the wall of the lateral ventricle and surrounded by gray matter [5].

Closed schizencephaly results in the identification of a linear signal of gray matter, extending from the cerebral surface to the wall of the lateral ventricle [6].

In addition to schizencephaly, other abnormalities such as polymicrogyria zones, heterotopy under ependymal, callous dysgenesis and an agenesis of the septum lucidum [7].

Surgery is often impossible to perform because of the central topography of the lesions and the presence of extensive epileptogenic zones.

\section{CONCLUSiON}

Schizencephaly is an uncommon cerebral malformation that is most often revealed by epilepsy.

It is characterized by a cleft with open or closed lips sitting most often in the Rolandic regions. Imaging including MRI is essential in the positive diagnosis and the lesion report.

\section{REFERENCES}

1. Oh KY, Kennedy AM, Frias Jr AE, Byrne JL. Fetal schizencephaly: pre-and postnatal imaging with a review of the clinical manifestations. Radiographics. 2005 May;25(3):647-657.

2. Dietermann JL. Les malformations corticales des hémisphères cérébraux. Neuro-imagerie diagnostique, 2007: 591.

3. Liang JS, Lee WT, Peng SS, Yu TW, Shen YZ. Schizencephaly: correlation between clinical and neuroimaging features. Acta paediatrica Taiwanica $=$ Taiwan er ke yi xue hui za zhi. 2002;43(4):208-213.

4. Poe LB, Coleman LL, Mahmud F. Congenital central nervous system anomalies. Radiographics. 1989 Sep;9(5):801-26.

5. Cottier JP, Toutain A, Hommet C, Sembely C, Bosq M, Texier N, Herbreteau D, Sirinelli D. Malformations corticales et épilepsie: apport de l'IRM. Journal de Radiologie. 2006 Nov 1;87(11):1621-34.

6. Patel AC, Cohen HL, Hotson GC. US case of the day. Open-lip schizencephaly with an area of heterotopic gray matter and associated absence of the septa pellucida. Radiographics. 1997 Jan;17(1):236-9.

7. Jerbi OS, Achour A, Younes S, Soua H, Sfar MT, Hamza HA. Unilateral closed-lip schizencephaly: MRI characteristics. Archives de pédiatrie: organe officiel de la Sociéte française de pédiatrie. 2012 Jul;19(7):762-764. 